\title{
A NEW PHRAGMIPEDIUM (ORCHIDACEAE: CYPRIPEDIOIDEAE) FROM ECUADOR
}

\author{
${\text { Phillip } \text { CRIBB }^{1} \& \text { Franco Pupulin }}^{2}$ \\ ${ }^{1}$ Royal Botanic Gardens, Kew, Richmond, Surrey, TW9 3AE, U.K. P.Cribb@rbgkew.org.uk \\ ${ }^{2}$ Jardín Botánico Lankester, Universidad de Costa Rica, P.O. Box 1031-7050 Cartago, Costa Rica. \\ fpupulin@cariari.ucr.ac.cr
}

\begin{abstract}
A new species of Phragmipedium, P. andreettae, is described and illustrated from northwestern Ecuador and its affinities are discussed. The new species is closely allied to $P$. fischeri, from which it differs by the narrow leaves, the pale rose to white flowers, the elliptic to obovate petals with reflexed margins, the reflexed margin of the dorsal sepal, the narrower and pale rose lip, and the longer than broad and bifid staminode.
\end{abstract}

Resumen. Se describe y se ilustra la nueva especie Phragmipedium andreettae, de la región noroccidental de Ecuador, y se discuten sus afinidades. La nueva especie está estrechamente relacionada con $P$. fischeri, de la cual difiere por las hojas más angostas, las flores rosado pálido a blanco, los pétalos elípticos a obovados con márgenes reflexos, el margen reflexo del sépalo dorsal, el labelo rosado pálido más angosto y el estaminodio más largo que ancho y bífido en el ápice.

Key words / Palabras clave: Orchidaceae, Cypripedioideae, Phragmipedium andreettae, Phragmipedium fischeri, Phragmipedium schlimii, Ecuador, new species

The genus Phragmipedium ranges from southern Mexico to Bolivia and eastern Brazil. The exact number of species in the genus remains contentious: 33 species have been described in the genus but several have been variously reduced into synonymy (Gruss 2003). McCook (1998) listed 15 species, whereas Gruss (2003) and Quené \& Gruss (2003) accepted 21 species. The exact number may well lie somewhere between these figures. Several of these have recently been described as new to science, including two, the red-flowered $P$. besseae Dodson \& J.Kuhn from Peru and Ecuador and the rose-purple flowered $P$. kovachii J.T.Atwood, Dalström \& Ric.Fernández from Peru, that are very distinct from any of the other species. The discovery of yet another species in Ecuador is, therefore, not that surprising.

A small-flowered species, allied to $P$. schlimii (Rchb.f.) Rolfe and P. fischeri Braem \& H.Mohr, has recently been collected in northwestern Ecuador in the same region where $P$. fischeri was discovered a decade ago. It has a similar habit and habitat to P. fischeri according to the collector, although exact details of the province are not available. It is similarly coloured to some pale forms of the Colombian P. schlimii but its lip and staminode shape are quite distinct, being differently coloured, longer than broad and distinctly, if minutely, bifid at the tip. The type plant was flowered in cultivation in the collection of Ecuagenera of Gualaceo, Ecuador, and the type has been deposited in the National Herbarium in Quito. It is named in honour of Padre Andreetta, the Salesian priest who has had a life-long interest in orchids and who inspired the Portilla family in the foundation and development of Ecuagenera.

\section{Phragmipedium andreettae P.J.Cribb \& Pupulin, sp. nova}

Species affinis Phragmipedio fischeri Braem et $\mathrm{H}$. Mohr sed foliis angustioribus, 1.2-2 cm latis (2.5-3 $\mathrm{cm}$ latis in P. fischeri), floribus pallide roseis vel albis, 
petalis ellipticis vel obovatis marginibus reflexis, sepalo dorsali margine reflexo, labello angustiore, $1.2-1.4 \mathrm{~cm}$ diametro (1.5-1.7 cm diametro in P. fischeri) pallido roseo, staminodio longiore quam latiore obtrullato ad apicem minute bifido distinguendo.

TYPE: NW Ecuador, sine prov., hort. Ecuagenera, November 2005, Portilla s.n. (holotype: QCA!). Fig. 1-2.

A lithophytic plant. Leaves linear, acute, up to $15 \times 1.3-2 \mathrm{~cm}$, mid-green. Inflorescence erect to arching-suberect, 13-16 cm long, unbranched or with one branch, flowers produced in succession; peduncle purple, finely white-pubescent; sterile bract on peduncle acute, 2-3 cm long, green; fertile bracts conduplicate, ovate-lanceolate, acute, $2-2.5 \times 1 \mathrm{~cm}$, green with a purple base. Flowers with pale pink sepals, white petals flushed with pale pink on back, and white staminode with a yellow central spot; lip pink with purple- and pink-spots and with a yellow stripe along the back wall within; pedicel and ovary $5.5-6.5 \times 0.2-0.3 \mathrm{~cm}$, purple, finely white-pubescent. Dorsal sepal elliptic, obtuse, $2.1-2.2 \times 1.2-1.3 \mathrm{~cm}$, lateral margins reflexed, finely pubescent on both surfaces; synsepal similar in shape, shorter than the lip, 2-2.2 x 1.6-2 cm, bi-keeled on reverse, margins reflexed. Petals elliptic to obovate, rounded, $2.4 \mathrm{x}$ $1.6 \mathrm{~cm}$, margins reflexed, finely white pubescent on inner surface. Lip urceolate, 2.1 x 1.2-1.4 cm, finely pubescent on outside; side margins incurved, more so at the base, hairy within and without. Column 0.6 $\mathrm{cm}$ long; staminode obtrullate, $0.7 \times 0.6 \mathrm{~cm}$, bifid at tip; anthers small, bilocular; stigma 4.5-5 $\mathrm{mm}$ long, spatulate, hidden by staminode.

Distribution. Known only from NW Ecuador; 500$1000 \mathrm{~m}$.

\section{Literature Cited}

Gruss, O. 2003. A checklist of the genus Phragmipedium. Orchid Digest 67(4): 213-241.

McCook, L. 1998. An annotated checklist of the genus Phragmipedium. Orchid Digest Special Publication.

Quené, R.-J.W. \& O. Gruss. 2003. Phragmipedium brasiliense, a new species of the section Lorifolia from Brazil. Orchid Digest 67(4): 242-243. 


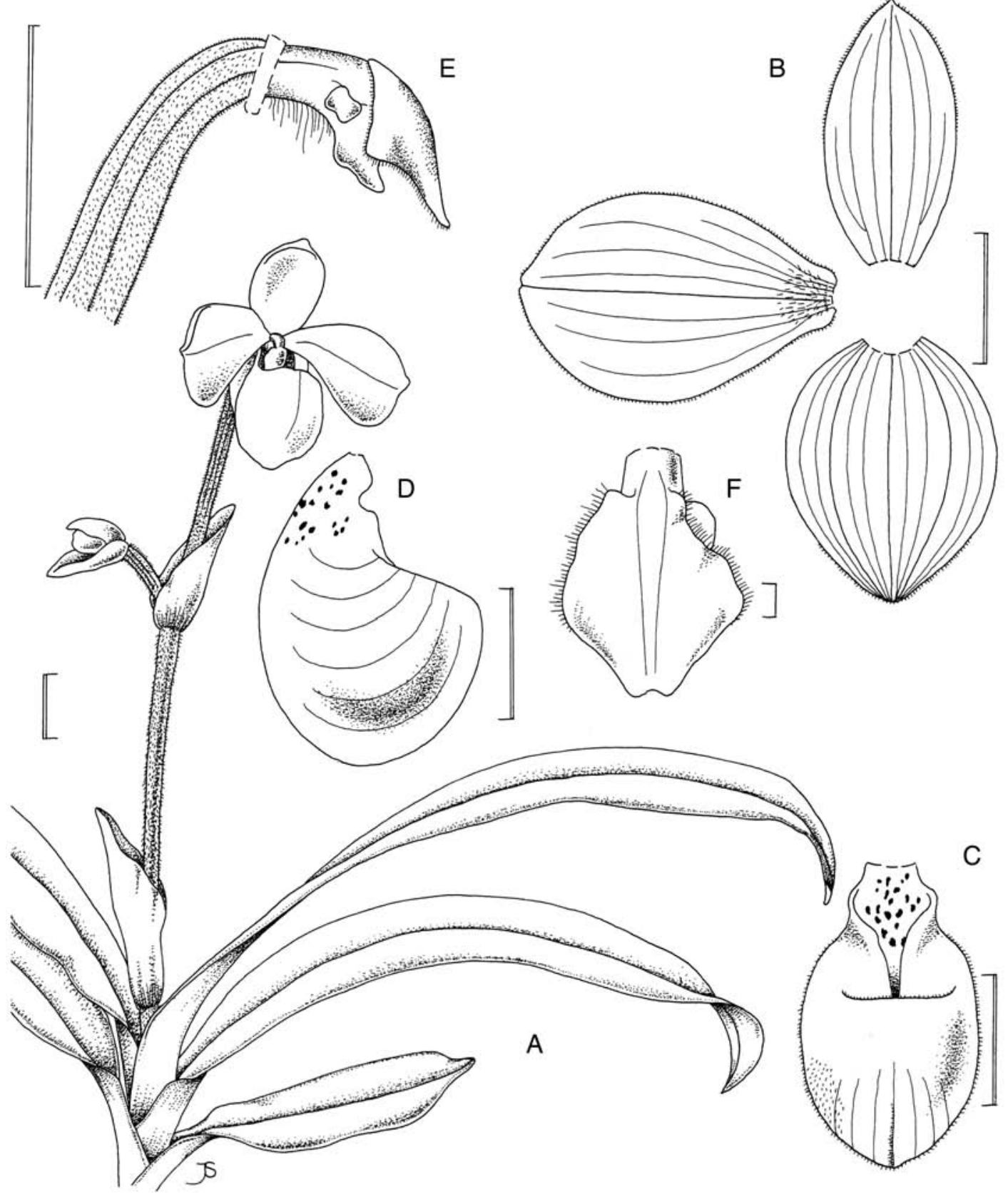

Fig. 1. Phragmipedium andreettae P.J.Cribb \& Pupulin. A - Habit. B - Sepals and petal. C - Lip, frontal view. D - Lip, lateral view. E - Column, lateral view. F - Staminode, frontal view. Single bar $=1 \mathrm{~mm}$; double bar $=1$ cm. Drawn by F. Pupulin from the holotype (Portilla s.n., QCA); inked and rendered by Judi Stone. 


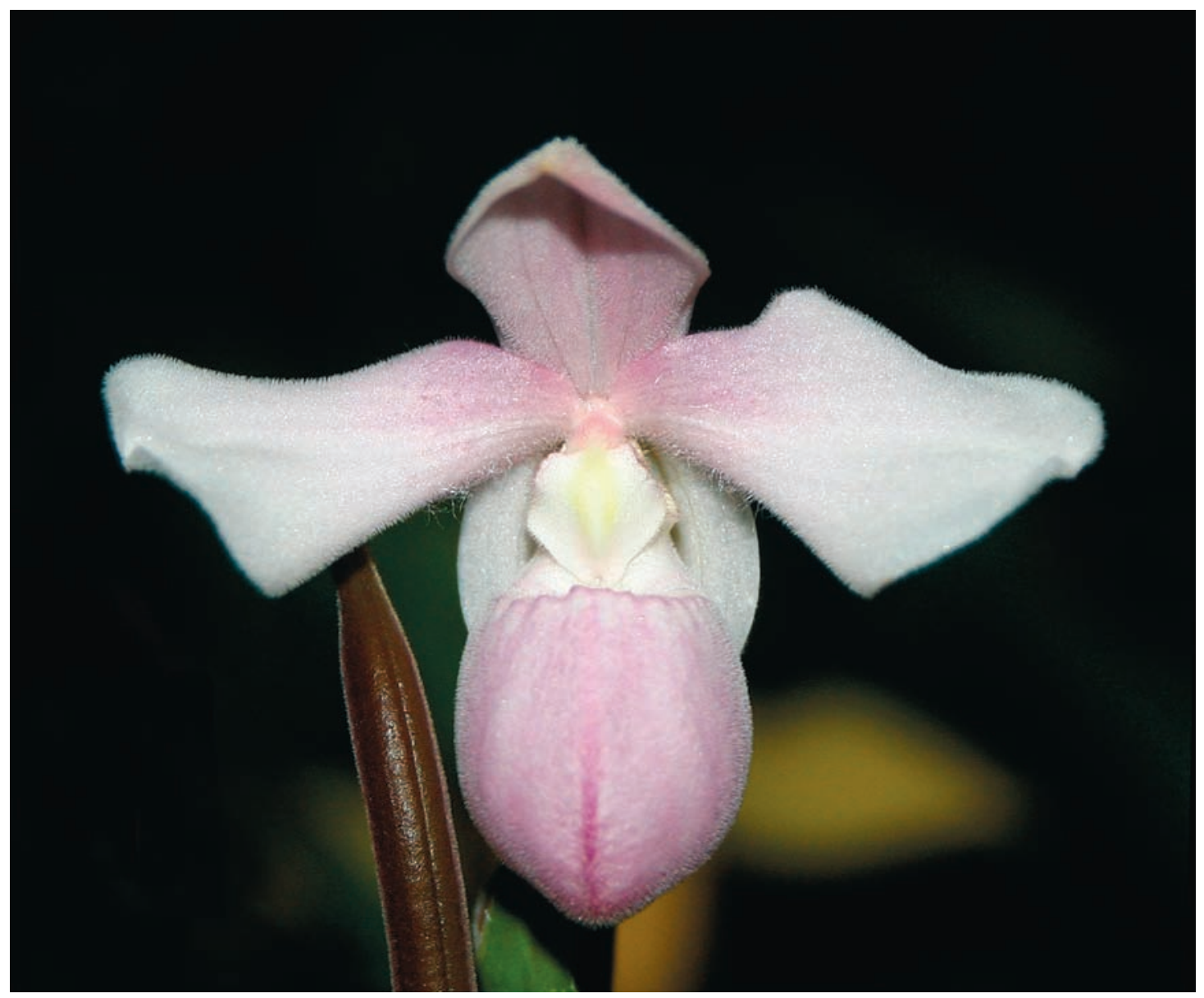

Fig. 2. Phragmipedium andreettae P.J.Cribb \& Pupulin. Frontal view of the flower that served as the holotype (Portilla s.n., QCA). 